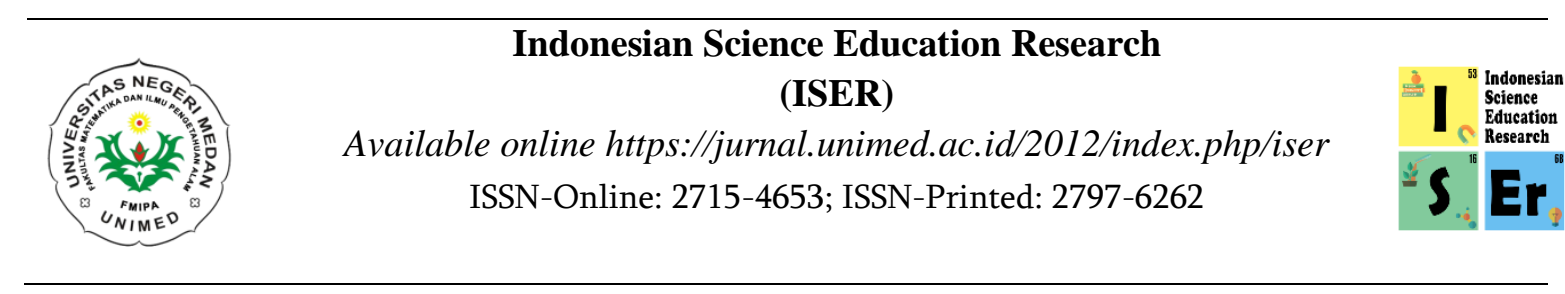

\title{
APPLICATION OF JIGSAW COOPERATIVE LEARNING MODEL TO INCREASE STUDENT LEARNING OUTCOMES IN ENGINEERING MECHANICAL LESSONS
}

\author{
Envilwan Berkat Harefa \\ Institut Keguruan dan Ilmu Pendidikan (IKIP) Gunungsitoli \\ envilwanharefa@gmail.com
}

Accepted: May 10th, 2021. Published: September 6th, 2021

\begin{abstract}
The problem in this study is the Jigsaw Cooperative learning model has not been applied optimally to engineering mechanics subjects and student learning outcomes do not meet the KKM standard of 70. The objectives of the study: (1) to describe the learning process in engineering mechanics subjects by applying cooperative learning models Jigsaw Type in Vocational Schools, and (2) To find out student learning outcomes in Mechanical Engineering subjects, especially in Basic Competence, apply how to arrange an equivalent style in building structures by applying the Jigsaw Type cooperative learning model in Vocational Schools This type of research is Classroom Action Research (CAR). This research was carried out in SMK with the research subjects of Class X students. The instruments in this study were observation sheets of the learning process, (teachers' respondents), student activity observation sheets, photo documentation, and learning outcomes tests. With the data analysis technique, the observation sheet was processed with a Likert scale and the learning outcomes test was carried out with a validation test and a feasibility test. The results of the study: (1) In the first (first) cycle the average percentage of observations in the learning process (teacher respondents) was 65\%, while in the second (two) cycle the average percentage of observations in the learning process (teacher respondents) was $85,37 \%$. (2) In the first (first) cycle, the average percentage of observation of student activity, which is $34.62 \%$, has not reached the target set, while in cycle II (two) the average percentage of observation of student activity, which is $88.46 \%$, has reached the target. set at $70 \%$. (3) In the first (first) cycle, the average count of student learning outcomes is 60.82 , the percentage value of student completeness is $30.77 \%$, while in the second (second) cycle, the average student learning outcome is 82.18 classified as good., and the percentage value of student learning outcomes completeness $92.31 \%$ has reached the target set, namely 70 . From the research findings above, it can be concluded that by applying the Jigsaw Type cooperative learning model to engineering mechanics subjects, it can improve student learning outcomes.
\end{abstract}

Keywords: Jigsaw Cooperative Learning Model, Learning Outcomes 


\section{Introduction}

In principle, education is a very important factor in the intellectual life of the nation. The success of a nation's development is closely related to education. According to Sanjaya (2007: 5) states that "The weak learning process developed by teachers today is one of the problems facing our education world". Therefore, the government always makes every effort to improve the quality of education.

Purwanto (2008:18) states that "Learning outcomes are quantitative measures that represent the abilities of students". The learning outcomes are said to be good if the learning outcomes obtained by students are always remembered and can be used in students' lives. The achievement of learning objectives is largely determined by the success of the learning process in the classroom, the success of teaching in the classroom is influenced by various factors, one of which is the interaction of teachers with students in learning. Teachers have a very important role in teaching and educating students as subjects who are the target of education.

Various problems that have been known from the results of observations include student learning outcomes that do not meet the Minimum Completeness Criteria (KKM) standards, then a solution arises to improve the way of learning to be better than the previous one, the researcher applies a learning model that allows students to interact each other, namely the cooperative learning model. This cooperative learning model can condition students to be active and provide mutual support in learning.

According to Rusman (2008: 215), the Jigsaw Type Cooperative learning model is learning that is carried out by encouraging students to express opinions and manage information so that students are directly able to improve communication skills from the material that has been studied. Each group consists of 4-5 people formed from heterogeneous members consisting of men and women from various ethnic groups, who have high, medium, and low abilities.

\section{Research Method}

The form of research is Classroom Action Research (CAR). In this study, researchers collaborate with subject teachers who act as observers and researchers as implementers of research activities. This Classroom Action Research aims to improve the learning process in the classroom.

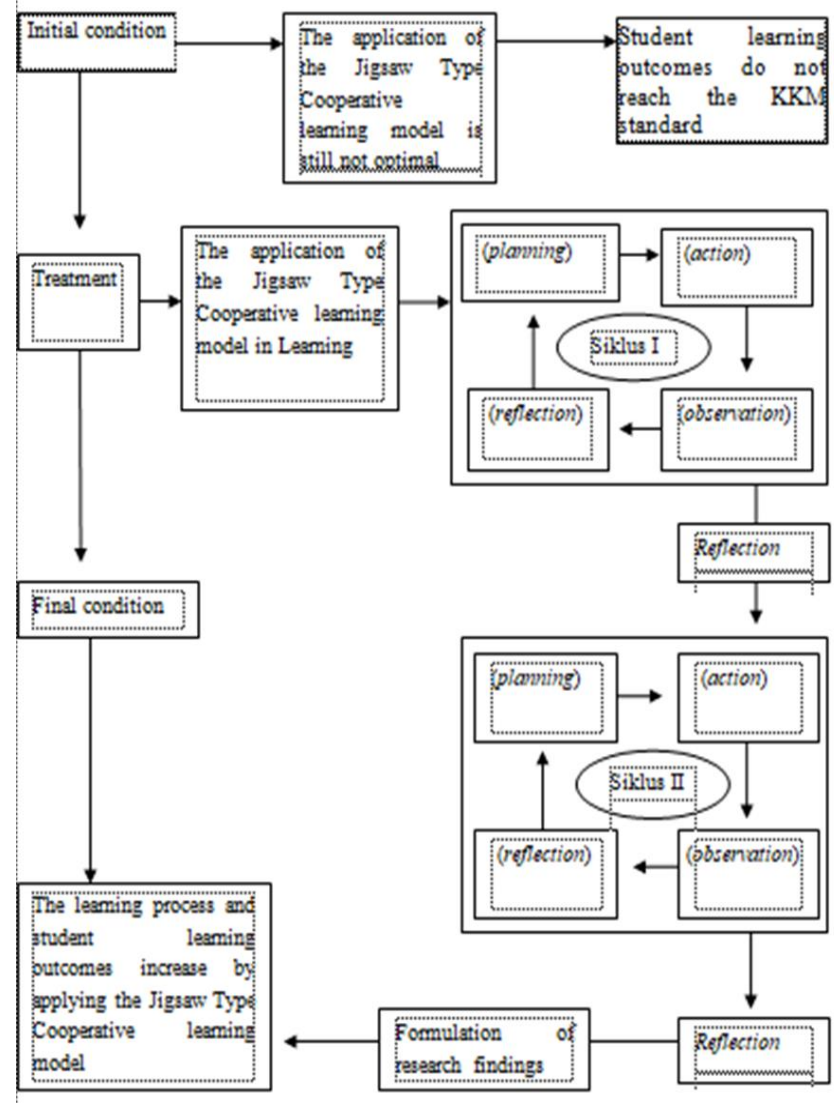

Fig. 1. Framework of thinking

\section{Result and Discussion}

This Classroom Action Research was conducted in class $\mathrm{X}$. The results of the class action research conducted using the Jigsaw Type Cooperative learning model showed an increase in student learning outcomes and the learning process was improved and became student-centered learning. In cycle I (one) the average student 
learning outcome is 60.82 (Appendix 10c) with a percentage value of student learning outcomes completeness of 30.77 (Appendix 10d table 16) and does not reach the set target of $70 \%$, then the research continued in cycle II.

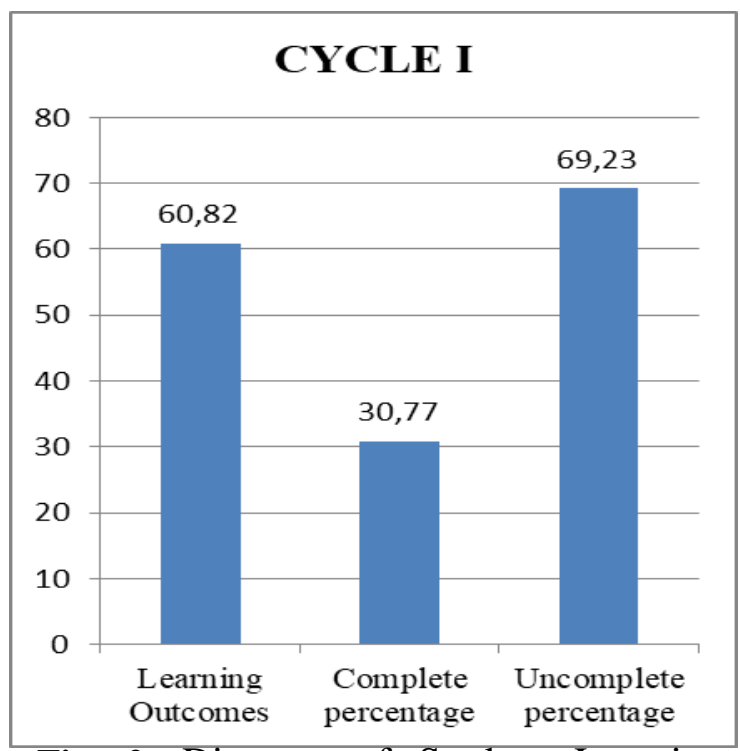

Fig. 2. Diagram of Student Learning Outcomes Cycle I

In cycle II (two) the average student learning outcomes have increased, namely 82.18 with a percentage value of student learning outcomes completeness of $92.31 \%$ and has reached the predetermined target of $70 \%$, then the research objectives are formulated, namely through the cooperative learning model. Jigsaw type, the learning process and learning outcomes increase.

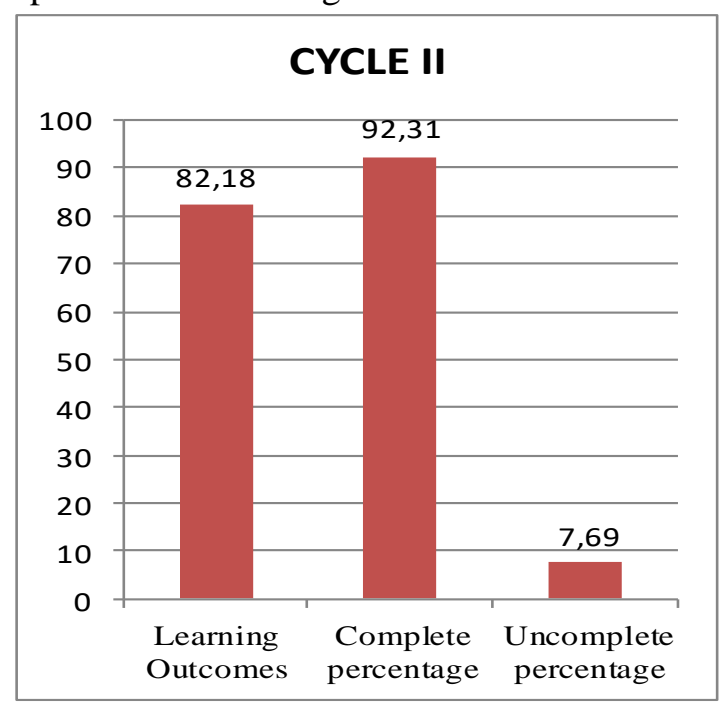

Fig. 3. Diagram of Student Learning Outcomes Cycle I
Furthermore, in cycle 2, the learning process was carried out by improving the weaknesses in cycle 1. Based on the observation sheet in the learning process of teacher respondents in cycle 2, it was known that the implementation of the learning process was getting better where some of the shortcomings in cycle 1 could be overcome. This can be seen in the increase in the percentage of observations on the implementation of the learning process of teacher respondents, which continues to increase. At meeting 1 it was $80.75 \%$ with good category and at meeting 2 it was $90 \%$ with very good category. In cycle 2 obtained the average student learning outcomes of 82.18 with a good category and the percentage of completeness of student learning outcomes of $92.31 \%$, this has reached the target that has been set. Based on the results obtained indicate an improvement in the learning process and good student learning outcomes by applying the Jigsaw Type Cooperative learning model in the learning process.

\section{Conclusion}

The application of the Jigsaw Type cooperative learning model can improve student learning outcomes in Mechanical Engineering subjects. This is evidenced in the second cycle (two) the average count of student learning outcomes has increased, namely 82.18 with a percentage value of completeness of student learning outcomes of $92.31 \%$, in the good category and has reached the target that has been set.

\section{Reference}

Arends. 1997. Model-Model Pembelajaran Inovatif Berorientasi Konstruktivis. Jakarta.

Ahmadi, Abu. 2009. Psikologi Pendidikan. Jakarta.

Arikunto. 2009. Prosedur Penelitian Suatu Pendekatan Praktik, Edisi Revisi 6. Jakarta : Rineka Cipta.

Bloom. 2004. Ukuran Keberhasilan Siswa Dalam Pembelajaran. Jakarta. 
.Huda, Miftahul. 2014. Model-Model Pembelajaran. Yogyakarta : Pustaka Belajar

Isjoni. 2009. Pembelajaran Kooperatif. Yogyakarta : Pustaka Belajar.

Istarani. 2012. 58 Model Pembelajaran Inofatif . Medan : Media Persada.

Kagan, Spencer. 1990. Kooperative Learning. San Juan Capristano : Kagan Kooperative Learning.

Murfihenni, Weni. 2013. Mekanika Teknik Semester 1. Jakarta : Kementrian Pendidikan dan Kebudayaan.

Purwanto. 2008. Evaluasi Hasil Belajar. Yogyakarta : Pustaka Pelajar.

Rusman. 2008. Manajemen Kurikulum "Seri Manajemen Sekolah Bermutu”. Bandung : Mulia Mandiri Perss.

Rusman. 2012. Model-Model Pembelajaran Mengembangkan Profresionalisme Guru. Depok : PT. Raja Grafindo Persada.

Slameto. 2003. Belajar dan Faktor-faktor Yang Mempengaruhi. Jakarta : Rineka Cipta.

Sanjaya, Wina. 2008. Perencanaan dan Desain Sistem Pembelajaran. Jakarta : Kencana Prenada Media Group.

Trianto. 2011. Mendesain Model Pembelajaran Inofatif Progresif. Jakarta: Kencana Prenada Media Group. 